\title{
Response of Different Fertilizer Level to Sweet Sorghum Cultivars in Rainfed Environment (Sorghum bicolor L. Moench)
}

\author{
Pritam O. Bhutada*, Jagdish Eknath Jahagirdar and G. M. Kote
}

AICRIP, Sorghum Research station, VNMKV, Parbhani, India

*Corresponding author

\section{Keywords}

Sweet Sorghum, Fertilizer, Growth and Yield,

Economy of Sweet

Sorghum

Article Info

Accepted:

15 May 2020

Available Online:

10 June 2020

\section{A B S T R A C T}

Sweet sorghum (Sorghum bicolor L. Moench) is identified as an industrial crop by virtue of accumulation of fermentable sugars in stem and the stalk syrup is an enriched source of bio ethanol. This experiment was carried out under open field condition to assess the response of different fertilizer levels on growth and yield production of sweet sorghum cultivars (G) in this agro climatic region. The experiment was conducted at Sorghum Research Station Farm, VNMKV, Parbhani during the year 2019-20. Factorial Randomized block design (FRBD) was used for the experiment. The total number of treatment combinations was $09\left(\mathrm{~F}_{3} \times \mathrm{G}_{3}\right)$ replicated thrice and total number of plots become 27. Application of fertilizer level $\mathrm{F}_{3}(125 \% \mathrm{RDF})$ i.e. 100:50:50 kg/ha recorded highest green \& dry fodder yield, GMR which was found at par with $\mathrm{F}_{2}$ level (100\% RDF) of fertilizer and found superior over fertilizer level.

\section{Introduction}

Now a days increase in population demand to focus production of bio-ethanol. The crops, such as maize, sugarcane and soybean gain unique importance. Three major groups categories as

Sucrose-containing feed stocks (Sugarcane, Sugar Beet, Sweet Sorghum and Fruits),

Starchy materials (Wheat, Rice, Potatoes, Cassava, Sweet Potatoes and Barley) and
Lingo-cellulosic biomass (Wood, Straw and Grasses). Among them Sorghum crop builds an importance in the global agro market that it can be used as a source of food, fiber, fuel, feed, and chemical/biofuels.

Sorghum is a leading tropical crop having larger genomes and more genes like sugarcane which is most promising crop of world's most efficient biomass-production and the leading bio-fuel source in the world (Paterson et al., 2009). Rao, et al., (2013) reported that sweet sorghum a choice bio- 
ethanol crop of the semiarid tropics in the sub-Saharan Africa and India. It is a crop of high universal value since it can be cultivated in tropical, subtropical, temperate and semiarid regions, as well as in poor quality soils of the world. It is termed "the sugarcane of the desert" or "the camel among crops" due to its drought hardy characteristics said by Sanderson, et al., in 1992.

Sorghum is a crop with good nitrogen $(\mathrm{N})$ use efficiency (Gardner et al., 1994). However, high $\mathrm{N}$ fertilization should be avoided since excessive $\mathrm{N}$ may reduce crop ethanol yield (Wiedenfeld, 1984) as well as considerably increase production costs and reduce energy efficiency, due to the fact that $\mathrm{N}$ fertilization accounts for up to $50 \%$ of the total energy input in arable crops (Kuesters and Lammel, 1999). Different cultivar may show independent responses according to environment factors (Alhassan et al., 2008). In this study a different level of fertilizer is combined in a variable manner with three cultivars of sweet sorghum in field condition and the proper yield efficiency is standardized by collecting data in parameters such as plant height, green \& dry fodder yield, and brix value etc with a repeated method. For good yield of sorghum plant proper balancing of exogenous nutrient input is necessary.

\section{Materials and Methods}

The research experiment was conducted during 2019-2020 at SRS, VNMKV, Parbhani Farm, The soil texture was mainly black cotton soil-clay loam with organic carbon low to medium and low in nitrogen, medium in phosphate \& high in potash, and $\mathrm{pH}$ range between 7.5 to 7.8. The experiment was arranged as a factorial randomized block design (3x3) where total treatment combinations were nine (09) with three (3) replications and each gross plot measuring $(6 \mathrm{~m} \times 5 \mathrm{~m})$.
Treatment combination used as Fertilizer levels (03) $\quad F_{1}: 75 \% \quad \operatorname{RDF}(60: 30: 30 \quad \mathrm{NPK}$ $\mathrm{kg} / \mathrm{ha}), \mathrm{F}_{2}: 100 \%$ RDF (80:40:40 NPK kg/ha) \& $F_{3}: 125 \%$ RDF (100:50:50 NPK kg/ha)., whereas Half dose of the nitrogen was applied as basal and another half as top dressing at 30 days after Sowing \& (03) three no of Sweet Sorghum cultivars: $\mathrm{G}_{1}$ : SPV- $2530, \mathrm{G}_{2}$ : CSV$19 S S \& G_{3}$ : CSV- 24SS was supplied from Indian Institute of Millets Research (IIMR). Row to Row $60 \mathrm{~cm}$ and Plant to Plant $10 \mathrm{~cm}$ spacing were maintained. Juice brix values were recorded by using hand refractometer (0- 202 Dr. Samarendra Barik, Pradip Roy and Satakshi Basu).

\section{Results and Discussion}

\section{Effect on plant height (cm)}

The effect of plant height on different fertilizer level and cultivars were showed significantly different from each other (Table1). Application of $125 \%$ RDF (100:50:50 NPK kg/ha) gave highest data $(343 \mathrm{~cm})$ at hatvest which was at par with $\mathrm{F}_{2}: 100 \% \mathrm{RDF}$ (80:40:40 NPK kg/ha) $(336 \mathrm{~cm})$.

This result indicated that increase of fertilizer level application plant height will be an increase similar result was found by Salvatore et al., (2012). On the other hand SPV- 2530 cultivar of sweet sorghum recorded highest plant height $(350 \mathrm{~cm})$ which was at par with CSV- 19SS $(348 \mathrm{~cm})$. Interaction effects between fertilizer level and cultivars on plant height gave non-significant effect.

\section{Effect on brix reading (\%)}

The results showed that the effect of sugar percentage $(\%)$ on fertilizer level, and cultivars were significantly different from each other (Table-1). Application of fertilizer $\mathrm{F}_{3}(125 \%)$ gave sugar percentage $(9.10 \%)$ at harvesting. 
Table.1 Effect of fertilizer levels on Parameters of sweet sorghum genotype in rainfed environment

\begin{tabular}{|c|c|c|c|c|c|c|}
\hline Treatments detail & $\begin{array}{l}\text { Plant stand } \\
\text { after thinning } \\
\text { (No) }\end{array}$ & Brix & $\begin{array}{c}50 \% \\
\text { flowering } \\
\text { (days) }\end{array}$ & $\begin{array}{l}\text { Plant } \\
\text { height } \\
(\mathbf{c m})\end{array}$ & $\begin{array}{l}\text { Steam } \\
\text { girth } \\
(\mathrm{cm})\end{array}$ & $\begin{array}{c}\text { No of } \\
\text { Leaves } \\
\text { per plant }\end{array}$ \\
\hline \multicolumn{7}{|c|}{ Fertilizer levels (F) (NPK kgha' $\left.{ }^{-1}\right)$} \\
\hline $\mathrm{F}_{1}: 75 \% \operatorname{RDF}(60: 30: 30)$ & 293 & 8.77 & 70 & 311 & 5.39 & 12 \\
\hline$F_{2}: 100 \%$ RDF(80:40:40) & 296 & 9.01 & 71 & 336 & 5.44 & 13 \\
\hline$F_{3}: 125 \% \operatorname{RDF}(100: 50: 50)$ & 297 & 9.10 & 70 & 343 & 5.44 & 13 \\
\hline SE+ + & 4.56 & 0.23 & 0.31 & 9.60 & 0.17 & 0.34 \\
\hline CD at $5 \%$ & NS & NS & NS & 29 & NS & NS \\
\hline \multicolumn{7}{|l|}{ Genotypes (G) } \\
\hline $\mathrm{G}_{1}: \mathrm{SPV}-\mathbf{2 5 3 0}$ & 296 & 8.84 & 71 & 350 & 5.22 & 13 \\
\hline $\mathrm{G}_{2}: \mathrm{CSV}-19 \mathrm{SS}$ & 291 & 9.13 & 70 & 348 & 5.44 & 13 \\
\hline$G_{3}: C S V-24 S S$ & 299 & 8.90 & 70 & 292 & 5.61 & 12 \\
\hline SE+ & 4.56 & 0.23 & 0.31 & 9.61 & 0.17 & 0.34 \\
\hline CD at $5 \%$ & NS & NS & NS & 2.87 & NS & NS \\
\hline \multicolumn{7}{|l|}{ Interaction (FXG) } \\
\hline SE+ & 0.49 & 0.40 & 0.54 & 16.64 & 0.30 & 0.59 \\
\hline CD at $5 \%$ & NS & NS & NS & NS & NS & NS \\
\hline CV \% & $8 \%$ & $8 \%$ & $1 \%$ & $9 \%$ & $10 \%$ & $8 \%$ \\
\hline G. Mean & 295 & 8.96 & 70 & 331 & 5.43 & 13 \\
\hline
\end{tabular}

Table.2 Effect of fertilizer level on yield sweet sorghum genotype in rainfed environment

\begin{tabular}{|c|c|c|c|c|c|}
\hline Treatments detail & $\begin{array}{c}\text { Green } \\
\text { fodder } \\
\text { yield } \\
\left(\mathbf{k g ~ h a}^{-1}\right)\end{array}$ & $\begin{array}{c}\text { Dry Fodder } \\
\text { yield } \\
\left(\mathrm{kg} \mathrm{ha}^{-1}\right)\end{array}$ & $\begin{array}{c}\text { GMR } \\
\left(\text { Rs ha }^{-1}\right)\end{array}$ & $\begin{array}{c}\text { NMR } \\
\left(\text { Rs ha }^{-1}\right)\end{array}$ & $\begin{array}{l}\text { B:C } \\
\text { ratio }\end{array}$ \\
\hline \multicolumn{6}{|c|}{ Fertilizer levels (F) (NPK kgha $\left.{ }^{-1}\right)$} \\
\hline$F_{1}: 75 \% \operatorname{RDF}(60: 30: 30)$ & 57875 & 40049 & 160197 & 129212 & 4.4 \\
\hline$F_{2}: 100 \% \operatorname{RDF}(80: 40: 40)$ & 64383 & 45324 & 181297 & 148976 & 5.56 \\
\hline$F_{3}: 125 \%$ RDF(100:50:50) & 72451 & 51902 & 207608 & 173951 & 5.51 \\
\hline SE+ & 3001 & 2203 & 8812 & 8812 & 0.21 \\
\hline CD at $5 \%$ & 8983 & 6595 & 26378 & 26378 & 0.63 \\
\hline \multicolumn{6}{|l|}{ Genotypes (G) } \\
\hline$G_{1}: S P V-2530$ & 59026 & 43440 & 173759 & 141438 & 5.0 \\
\hline$G_{2}: C S V-19 S S$ & 70322 & 49169 & 196676 & 164355 & 5.5 \\
\hline$G_{3}: C S V-24 S S$ & 65359 & 44667 & 178667 & 146346 & 5.0 \\
\hline SE + & 3001 & 2203 & 8812 & 8812 & 0.2 \\
\hline CD at $5 \%$ & NS & NS & NS & 26378 & 0.63 \\
\hline \multicolumn{6}{|l|}{ Interaction (FXG) } \\
\hline SE+ & 5198 & 3816 & 15263 & 15263 & 1 \\
\hline CD at $5 \%$ & NS & NS & NS & NS & NS \\
\hline CV \% & $14 \%$ & $14 \%$ & $14 \%$ & $17 \%$ & $12 \%$ \\
\hline G. Mean & 64903 & 45759 & 183034 & 150713 & 5.16 \\
\hline
\end{tabular}


This result indicate that increasing nitrogen application helps to improved sweet sorghum sugar percentage but Ramadan (2003) found that increasing nitrogen rate up to $100 \mathrm{~kg} / \mathrm{fed}$ markedly increased stalk diameter, stalk length and reducing sugar as well as stalk yield and syrup yield. On the other hand CSV- 19SS cultivars of sweet sorghum showed highest sugar percentage $(9.13 \%)$. In case of Interaction effects between fertilizer level and cultivars on Brix reading (\%) was not found significant.

\section{Effect on green \& dry fodder yield}

The results showed that the effect on Green fodder yield of fertilizer level, and cultivars were significantly different from each other (Table-2). Application of fertilizer $\mathrm{F}_{3}(125 \%)$ recorded higher green \& dry fodder yield (72451 \& $51902 \mathrm{~kg} / \mathrm{ha})$ which was at par with fertilizer level $\mathrm{F}_{2}(100 \%)(64383 \& 45324$ $\mathrm{kg} / \mathrm{ha}$ ). This result indicated that increasing fertilizer level of application helps to improved sweet sorghum green \& dry fodder yield. Tran Dang Xuan (2016) also reported that non application of any $\mathrm{N}, \mathrm{K}_{2} \mathrm{O}$ and $\mathrm{P}_{2} \mathrm{O}_{5}$ caused severe marked reduction of stem yield, up to 20 tons/ha and the amount of $\mathrm{N}$ played a more significant role on the yield of this crop. The biomass yields of sweet sorghum have been reported to vary across a range of nitrogen (N) fertilizer rates, cultivars, and plant populations. Wortmann et al., (2010) reported dry stalk yields from 8 to 48 metric ton $\mathrm{ha}^{-1}$ across a range of $\mathrm{N}$ fertilization rates, cultivars, and plant populations.

\section{Economic study}

The results showed that (Table-2) level of fertilizer $\mathrm{F}_{3}(125 \% \mathrm{RDF})$ recorded highest GMR (207608 Rs/ha) which was at par with fertilizer level $\mathrm{F}_{2} \quad(100 \%$ RDF) (181297 $\mathrm{Rs} / \mathrm{ha})$. But in case of NMR \& B:C ratio $\mathrm{F}_{2}$ (100\% RDF) fertilizer level recorded highest
(148976 Rs/ha \& 5.56) which was at par with fertilizer level $\mathrm{F}_{3}(125 \% \mathrm{RDF})$. Interaction effects between fertilizer level and cultivars on green \&dry fodder yield and economics study was found non-significant effect.

\section{References}

Alhassan, U., Yeye M.Y., Aba, D.A, and Alabi, S.O.( 2008) "Correlation and path coefficient analyses for agronomic and malting quality traits in some sorghum (Sorghum bicolor (L.) Moench) genotypes". Journal of Food, Agriculture and Environment., 6(3\&4),pp-285-288.

Barik S., Roy P,(2015) “Agronomic practices for the development of sweet sorghum [Sorghum bicolor (L.) Moench] crop in Birbhum district of West Bengal" Research on Crops, Volume: 16, Issue : 2 , pp-230- 235.

Gardner, J. C. , Maranville, J. W. and Paparozzi, E. T. (1994) "Nitrogen use efficiency among diverse sorghum cultivars". Crop Sci, 34, pp-728-733.

Kuesters,J. and Lammel J.(1999) "Investigations of the energy efficiency of the production of winter wheat and sugar beet in Europe". Eur J Agron, 11, pp-35-43.

Paterson, E., Bowers, J., Bruggann, R. and Inna, D. (2009) "The Sorghum bicolor genome and the diversification of grasses". Nature, 457, pp- 551-553.

Ramadan, B.S.H., (2003)“'Effect of nitrogen, phosphorus and potassium fertilization on growth, yield and quality of sweet sorghum Proc". 10 Conf. Agron. Suez Canal Univ. Fac. Environ. Agric. Sci. EL-Arish, Egypt.

Rao, P. S., C. G. Kumar, and B. V. Reddy, Sweet sorghum: from theory to practice, in Characterization of Improved Sweet Sorghum Cultivars, P. S. Rao and C. G. Kumar, Eds., SpringerBriefs in 
Agriculture, pp. 1-15, Springer, New Delhi, India, 2013

Salvatore, L.C., Mantineo, M. and Testa, G. (2012) "Water and nitrogen balance of sweet sorghum (Sorghum biocolor Moench (L) cv. Keller under semi-arid conditions" Industrial Crops and Products, 36,pp-329-342.

Sanderson, M. A., R. M. Jones, J. Ward, and R. Wolfe, "Silage sorghum performance trial at Stephenville," Forage Research in Texas. Report PR-5018, Texas Agricultural Experiment Station, Stephenville, Tex, USA, 1992.

Soileau, J. M. and B. N. Bradford, "Biomass and sugar yield response of sweet sorghum to lime and fertilizer," Agronomy Journal, vol. 77, pp. 471475, 1985

Tran Dang Xuan, Nguyen Thi Phuong and Tran Dang Khanh (2016).Effects of
Fertilizers on Biomass, Sugar Content and Ethanol Production of Sweet Sorghum February 22nd 2017. DOI: $10.5772 / 66814$ book chapter https://www.intechopen.com/books/bio mass-volume-estimation-andvalorization-for-energy/effects-offertilizers-on-biomass-sugar-contentand-ethanol-production-of-sweetsorghum

Wiedenfeld, P. R. (1984) "Nutrient requirements and use efficiency by sweet sorghum". Energ Agr. 3,pp-4959.

Wortmann, A. J. Liska, R. B. Ferguson, D. J. Lyon, R. N. Klein, and I. Dweikat, "Dryland performance of sweet sorghum and grain crops for biofuel in Nebraska," Agronomy Journal, vol. 102, no. 1, pp. 319-326, 2010

\section{How to cite this article:}

Pritam O. Bhutada, Jagdish Eknath Jahagirdar and Kote. G. M. 2020. Response of Different Fertilizer Level to Sweet Sorghum Cultivars in Rainfed Environment (Sorghum bicolor L. Moench). Int.J.Curr.Microbiol.App.Sci. 9(06): 645-649. doi: https://doi.org/10.20546/ijcmas.2020.906.082 